\title{
Hargomulyo Citizens 'Obstacles in Choosing a Leader
}

\author{
Ardi Ashadi*1, Widodo ${ }^{2}$ \\ STKIP Kumala Lampung ${ }^{* 1}$, STIE IPWI Jakarta ${ }^{2}$ \\ Ardhiashadi@kumala.ac.id ${ }^{* 1}$, widodomurnasih@gmail.com²
}

\begin{abstract}
Citizen Hargomulyo has determined a leader which can be expected to protect its people is more when commutation moment hence people surely hope the leader which will be better in holding governance wheel. At this opportunity is writer starts from a survey later; then communicates with the society either through direct and also through passing media social later; then does conduct this research with the descriptive method qualitative. Hence at this opportunity is a writer will pare and explain what citizen resistance in choosing a leader. Candidate resistance is: Less be recognized although often have socialization to $5 \%$. Socialization less $7 \%$, A lot of promise $13 \%$. Experience in society $4 \%$. Less go into society $9 \%$. Successful Team does not solicit $10 \%$. graceless Successful Team 9\%. in government 7\%. Education 4\% campaign Negative 17\% and kinds of resistance in the content of according to elector experience $6 \%$.
\end{abstract}

Keywords: Leader; Resistance

\section{INTRODUCTION}

Leaders have recently been encouraged to achieve Quality Improvement Management in Organizations or agencies (MPM), which is a job management model that provides broader autonomy to organizations or agencies to make participatory decisions by involving all members of the organization or agency.

Because the role of the leader in the organization is very important, it is the main obligation for every leader to always try, observe and understand the behavior of subordinates, look for and determine the behavior of subordinates, take into account, supervise and change and direct the behavior of subordinates to carry out tasks accordingly. with its functions, especially those related to rural governance, are the responsibility of the Village Head. So that organizational goals can be achieved according to plan.

If every life of an organization is carried out a careful observation, it will be clearer that the role of administrative management through the actions of planning organizing, directing, coordinating, controlling, and evaluating as well as communication developed by the Village Head as an administrator, to realize effective and effective work. directed with a specific goal.

In the life of a government organization, if it is observed and observed there will be a process of cooperative interaction between leaders and subordinates who are considered, directed, fostered, and developed, but may also be forced so that this behavior is following the expectations of leaders in an institution.

In the contemporary era, organizations are based on dependence (Dependency) and prediction (Proximity) as a result of technological advances and population development, so that the notion of organization develops following the interaction between the formal system and human components. So, the government organization is a forum that functions to organize the community service process.

To implement, manage, manage, and organize management is needed, namely the process of leading, guiding, preparing facilities for subordinates to work together to achieve common goals.

The motive of society is a hope that chases both the future hope of itself and the hope of the future that is generated by the actions of others. 
Often, the leadership of the organization comes from other organizations or institutions not previously known by employees or subordinates who have the basics, competencies, and leadership qualities, and individual attitudes.

Based on the background of the problem above, the author considers it important to study the problem of community motivation in choosing leaders in Hargomulyo Village, Gedangsari, Gunungkidul, to observe problems that arise and find the best solution.

The village head, as the leader who controls the organization, is very important and strategic in the context of economic development and no less important as a motivator and role model. If these two things do not go well, there will be a decline and a decrease in the mission that is carried out is not following what is expected by the community.

So, the authors want and are interested in conducting research related to the matters above, for this research the author presents the research title "The motivation of the community in choosing leaders in Hargomulyo Village, Gedangsari, Gunungkidul."

Citizen barriers: Barriers are limitations or shortcomings in resources, skills, and capabilities that effectively hinder company performance. These limitations can be in the form of facilities, financial resources, management capabilities, and marketing skills that can be the source of a company's weakness (Paksmp16kupangblog, 2016).

Humans are never separated from relationships with humans or other communities in an association. People who have little interaction with other communities' experience slow change. This is because people do not know the development of other societies that can enrich their own culture. They are supported in their culture and in their traditional (simple) way of thinking.

Namely analysis of weaknesses, situations, or conditions which are weaknesses of an organization or company at this time. Is a way of analyzing weaknesses in a company or organization that are serious obstacles to the progress of a company or organization.

The obstacle in doing is trying in such a way as to do good, but the results are not as good as expected. Humans create various tools to help and facilitate human work, but tools created by humans often endanger human life itself.

Leader: Leaders have recently been encouraged, in line with the implementation of leading an organization or agency in the context of Quality Improvement Management in Organizations or agencies (MPM), which is a work management model that provides broader autonomy to organizations or agencies to make decisions in a participatory manner by involving all citizens of organizations or agencies.

Leadership is an important aspect for a leader because a leader must act as a group organization to achieve what has been determined. Accorrding to Baharudin \& Umiarso, (2012), Leadership is an activity of influencing others so that people are willing to work together (collaborate and collaborate on their potential) to achieve the goals that have been set. In other words, leadership is an ability in order to influence the group to achieve the group's goals (Muhani et al., 2016).

Yamin \& Maisah (2010) leadership is an influencing process carried out by a person in managing his group members to achieve organizational goals. Leadership is a form of strategy or leadership theory that is certainly carried out by people who we usually refer to as leaders. A leader is someone with the leading authority who directs his subordinates to do some of his work in achieving goals. Leadership according to Usman (2013) is (1) actions influence others to achieve the desired end goal; (2) influencing society, subordinates, institutions, and students; (3) guidance to realize the vision and so on, and (4) persuading subordinates to convey their interests. In contrast to other notions, leadership can be defined as a person's ability to move, direct and influence the mindset, the way each member works to be independent in work, especially 
in decision making for the benefit of acceleration achievement of predetermined goals (Wahyudi, 2017).

According to opinion, leadership is translated into traits, personal behavior, influence on others, patterns, interactions, cooperative relationships between roles, positions of one administrative position, and persuasiveness, and perceptions of others about the legitimacy of influence.

From several definitions of leadership according to the experts above, it can be concluded that leadership is a way for a leader to influence subordinates with certain characteristics so that they can achieve the desired goals. The success factors of a leader, among others, depend on leadership techniques in creating situations that cause the people they lead to arise awareness to do what they want and maps in the division of labor, must cooperate sincerely, there is motivation in workers, both material and moral, there are leaders and so on. The leader must carry out the controlling function (controlling), because:

So that there are no deviations in carrying out the predetermined plan.

Must measure whether the results are achieved according to plan. Based on the theory of obstacles and leaders, the people of Hargomulyo have set indicators to choose a candidate for a leader (Village Head) who they hope will be their ideal leader. These indicators are: (1) Less well known although often socializing; (2) Lack of socialization; (3) Plenty of promises; (4) Not yet experienced in society; (5) Lack of community (6) Team success is not solitary; (7)Team success is not attractive; (8) Lack of experience in government; (9) Education; (10) Negative campaign; (11) ... are filled in according to the voter's experience.

\section{METHODS}

This research was conducted in Hargomulyo Village, Gedangsari District, Gunungkidul Regency, Yogyakarta Special Region Province, in 2020. The research conducted by the author was to find out what the real obstacles to residents were when they made choices in village head elections, therefore the type of research used was survey and interview research. By using this type of research, it is hoped that it will be able to dig up information about the barriers to residents and will get a picture of the high and low barriers of the community to the election of the village head.

Therefore, this research is descriptive qualitative in nature, because it is not based on absolute numbers but explores the real motives or expectations of the community towards their prospective leader, in this case, are the village heads to be elected.

\section{RESULTS AND DISCUSSION}

Hargomulyo, Saturday, October 192019 The Pilkades Committee of Hargomulyo Village, Gedangsari District, Kab. Gunungkidul carries out the stages of Questionalization and the Declaration of the Peaceful Pilkades. The event was held in the Hargomulyo village hall starting at 9.00 WIB and was attended by the Head of Gedangsari Sub-district, Forkompinca key. Gedangsari, Village Government, and community leaders. The signing of the Peaceful Pilkades Declaration by the Village Head Candidates was witnessed directly by the Gedangsari Sub-District Head, Gedangsari Police Chief, Gedangasari Danramil, and Plt. Village head.

The Village Government hopes that all Hargomulyo people will maintain harmony and support the peaceful parkades to create safe, peaceful, and cool parkades. On Wednesday, 16 October 2019, the Hargomulyo Village Head Election Committee has carried out the Stages of Determining the Permanent Voters List for the Village Head election for the 2020-2025 term. Based on the results of the updating of the Voters List 
that had been carried out by the Voter Data Update Officer (PPDP) and based on the evaluation of updating voter data with Hamlet in Hargomulyo Village, the voter lists that had been determined by the Pilkades election committee were as follows:

Table 1. Recapitulation of Fixed List Selection of the Chairman of Hargomulyo Village in 2019

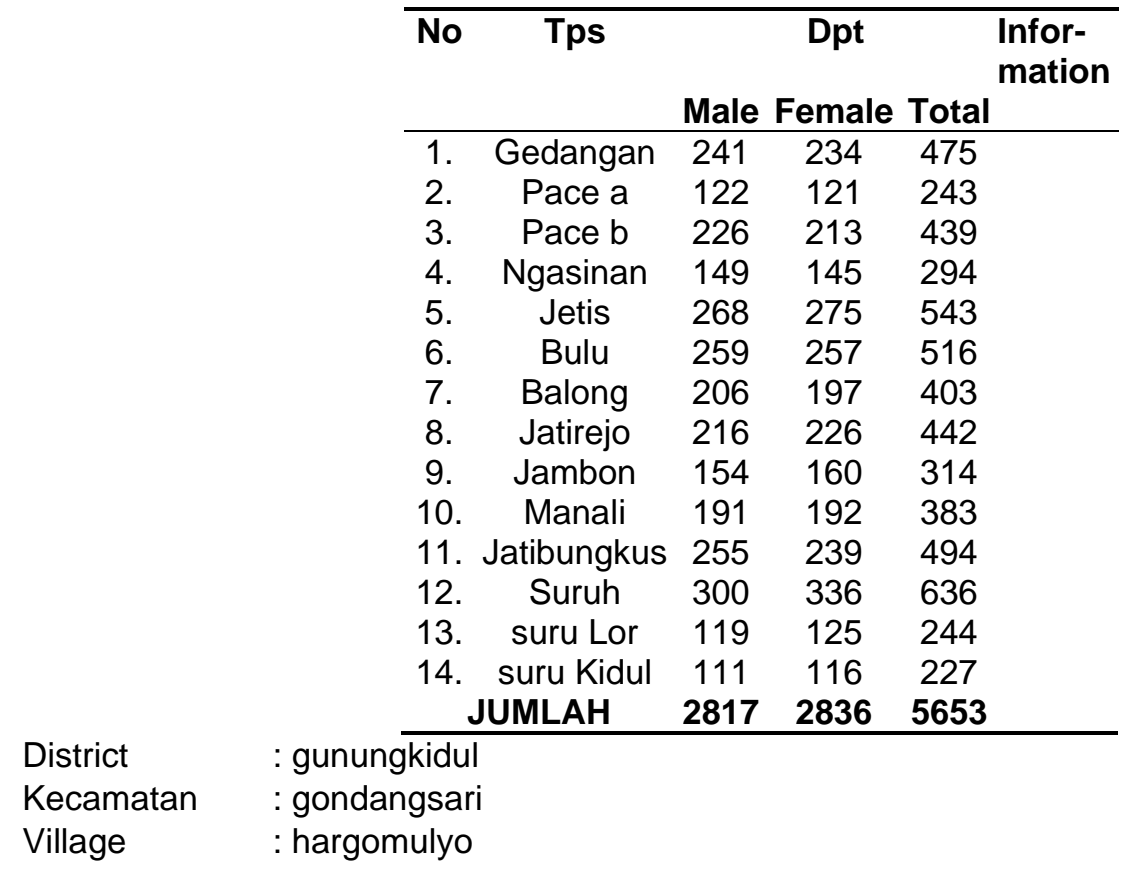

Source: Research results (2020)

The event was attended by the Secretary of the Gedangsari Sub-district, Gedangsari District Military Command, Hargomuly Village Babhinkamtibmas, the Chairman of the BPD, the Acting Village Head along with the apparatus and 2 Village Head candidates who were determined on October 14, 2019.

Furthermore, this final voter list is stated in the regulation of the Village Head Election Committee number 8 / KPTS / 2019 of 2019 concerning the Stipulation of the Permanent Voters List for Village Head Election for the 2020-2025 Term.

The Stages of Hargomulyo Village Head Election on Monday, October 142019 have entered the Number Drawing Stages and the determination of Village Head Candidates. Of the two prospective candidates who registered as candidates for village head, all of them met the requirements to take part in the drawing stages and determining the candidate for village head. The stages carried out in the Hargomulyo Village Hall Pendopo Hall were attended directly by the Head of the Gunungkidul Regency DP3AKBPM \& D Office Mr. Sujoko, S.Sos, M.Si, Head of Gedangsari Sub-District represented by the Head of Governance Section, Head of Gedangsari Police, Danramil Gedangsari and BPD of Hargomulyo Village.

In his remarks, the Head of the DP3AKBPM \& D Office of Gunungkidul Regency appreciated the performance of the Hargomulyo Village Head Election Committee which has worked well so that all processes and stages of village head elections in Hargomulyo Village can run well and are following the stages set by the Regent of Gunungkidul. Also, he appreciated the implementation of number drawing and the determination of the 
Village Head Candidate in Hargomulyo Village to run safely and in an orderly manner so that there was no friction between candidate supporters.

Furthermore, before the number drawing process was carried out, Mr. Arif Munasir as the Head of the Village Head Election Committee read out the Decree of the Village Head Election Committee regarding the Determination of prospective village head candidates as the basis for the Draw Number and the Determination of Candidates for the Village Head of Hargomulyo. The essence of this decision is that 2 registrants who have submitted their application documents as a candidate for village head can be accepted and can participate in the number drawing process and the Village Head Candidate Determination.

From the results of the implementation of the Number Draw, the results for the number of each candidate are as follows:

(1) Ms. Marsinem, S.Sos, M.Si received serial number

(2) Mr. Sumaryanta received serial number

Based on the results of the lottery numbers that have been obtained, the Village Head Election Committee Decree No. 7 / KPTS / 2019 on the Village Head Candidates signed by the head of the Village Head Election Committee Mr. Arif Munasir.

Today, Saturday, September 21, 2019, the Village Head Election Committee, Hargomulyo Village, Gedangsari District, Gunungkidul Regency, is conducting socialization on the rules for village head elections. as for the rules of the Pilkades attached.

Training of Voter Data Update Officer (PPDP) at Hargomulyo Village PILKADES in 2019 (Tuesday, 17/9/19). The training was carried out by the Village Head Election Committee, Hargomulyo Village, Gedangsari District, Gunungkidul Regency which was attended by the Village Head and the Gedangsari District FORKOMPINCA went smoothly and following the Pilkades stages simultaneously. With this training, the Village Government hopes that the updating of voter data can run smoothly according to the applicable regulations so that a Provisional Voters List (DPS) can be established according to the simultaneous Pilkades stages in Gunungkidul Regency.

The atmosphere heated up ahead of Pilkades in Hargomulyo Village, Gedangsari District. Two candidates clash with each other regarding their superior program. The beginning of this polemic began when one of the candidates, Marsinem, in his campaign stated that he would eliminate the apostolic event when he took office. This program was then attacked by another incumbent village head candidate, Sumaaryanta, who considered the program irrelevant to the conditions of Hargomulyo Village.

To pidjar.com, Marsinem was adamant that he would implement the program if he was elected Head of Hargomulyo Village. According to him, this kind of event can be obtained funding without having to burden the community. There are quite a lot of successful overseas residents as well as sponsors who can work together to finance apostles in their villages. In addition to being free, he also guaranteed that the apostles would still run happily.

"Following my statement to the public, for this free messenger, the mastermind is at least Ki Seno," said Marsinem, Thursday (31/10/2019) afternoon.

One of the reasons for this desire is that his party feels the need to reduce the burden on society. So far, for each apostle, the community has been charged Rp.30,000 per family. This number may not be a problem for people with middle and upper economies. But of course, this will be a burden for people with weak economies. 
"I have my dream, that in the future the event that must be held because it has become a tradition can be without burdening the village government budget," he explained.

Regarding the attacks he received in connection with this program, Marsinem admitted that he could not stop thinking. He called the accusation that not collecting money from the community would undermine cooperation, he called it absurd. Marsinem stated that cooperation should not be valued in money. Gotong royong is the intention of the community to move together and help each other.

"This is precisely what I will develop if I get the mandate. We want people to have a sense of belonging to each other so that this is manifested in activities, such as community service, providing mutual assistance to poor people. This is the true essence of cooperation," explained Marsinem.

This free apostle is not the flagship program. Several things attract attention to be fixed or improved. Among them are bureaucratic reform within the village government to improve services to the community. In the era of his leadership, services must be fast so that people can feel comfortable and do not waste time.

"I also want to develop the people's economy, Hargomulyo must be prosperous," said Marsinem.

Separately, one of the Hargomulyo community leaders, Mulyono, said that the idea of free apostleship was very possible to be realized. He even personally pockets to pay for the puppet event with puppeteer Ki Seno. However, he will provide this regularly with a note that the leader, in this case, the village head, can make changes.

Table 2. Recapitulation of Selection Results Head of Hargomulyo Village In 2019

\begin{tabular}{|c|c|c|c|c|c|c|c|}
\hline No & $\begin{array}{c}\text { Candidate } \\
\text { name }\end{array}$ & Acquisition & Information & Percentage & $\begin{array}{c}\text { Number of } \\
\text { DPT }\end{array}$ & $\begin{array}{c}\text { Sound } \\
\text { came in }\end{array}$ & $\begin{array}{l}\text { Valid } \\
\text { vote }\end{array}$ \\
\hline 1 & $\begin{array}{l}\text { Marsinem, } \\
\text { S.Sos M.Si }\end{array}$ & 1.559 & 2 & $35,34 \%$ & 5.653 & 4.476 & 4.412 \\
\hline 2 & Sumaryanta & 2.853 & 1 & $64,66 \%$ & & $79,18 \%$ & $98,57 \%$ \\
\hline
\end{tabular}

Source: Research results (2020)

Based on the results of all the answers from the public in answering the indicators that have been researched through Short Message Service (SMS), telephone, direct interviews, Facebook (Fb), and WhatsApp (WA), the highest answers are taken as follows:

Based on the indicators that the author has determined; answers are obtained from 100 people whom the author met both through social media and directly as follows:

Respondents who answered were less well known even though they often socialized as much as five or $5 \%$, according to voters that the candidates were not well known because indeed when socializing they were more dominated by brand success teams, so more often the successful teams socialized to the community. This makes the candidate not known by the voters in-depth, both nature and attitude that the voters still feel gray. According to voters, whether this candidate is serious about advancing the village or is it just for a stepping stone to a higher level in the future. So voters, if only as a stepping stone, must think again about choosing the candidate. 
Seven voters felt they had never been visited by a candidate, so those who answered that they were not socialized were $7 \%$, according to those whom the authors met, that the seven respondents only knew their success team. Therefore, according to the respondent, what the successful team said was not the heart and the vision and mission of the candidate. According to them also that the successful team threw negative words to each other against political opponents, so this made the public less sympathetic so that it became an obstacle for candidates.

According to residents, there is little interest that a candidate is considered to have too many promises, it is evident that $13 \%$ of the 100 residents who the author took the sample answered many promises. It was proven over and over again by the respondent that every candidate who campaigned always promised all kinds of things, but after being successfully elected, the candidate's promise was not realized. Therefore, for voters, it has become a tradition that candidates always promise and citizens do not respond with promises like that.

Voters have determined that experience is necessary so there is $4 \%$ who think that minimal experience or never holding the government is not the first choice. According to the respondents whom the author met, experienced candidates will find it easier to carry out government capabilities.

In the 2019 Pilkades, there were 9\% of respondents chose candidates because they were not sociable. According to the respondent, the candidate has never been to their house so they do not know exactly what conditions are in their place. If you look at the answers, there are indeed candidates who live in other areas so far, therefore it is only natural that there is a hamlet that has not been touched by the candidate.

There are $10 \%$ of respondents who choose that the successful team is not solitary. According to respondents, successful teams have different ideas and ideas and answers in one team. Therefore, this is the basis that the respondent is less sympathetic to the candidate. Because a team that is not solitary will reduce people's trust.

According to respondents, the success team was not attractive, so $9 \%$ said that. Respondents argued that respondents only seemed to care about themselves, not to candidates, and did not respect the wishes of the community. Successful teams sometimes feel they know better and feel that what they are thinking is thinking. The success team seems exaggerated so that respondents as part of the voters are less enthusiastic about the candidate.

Lack of experience is part of the candidate's obstacle in running so that $7 \%$ of respondents have provided evidence that inexperience is one of the reasons. According to respondents, a candidate with inexperience will experience delays and cannot even take policies in advancing the region they lead. The respondent stated that experience is a very valuable teacher so that after all a candidate who has experience will find it easier to hold the reins of leadership in government.

There are $4 \%$ who stated about education, according to them that the higher education will affect the mindset and actions and policymaking. Therefore they stated that the basis of education would be a guide or a foothold in holding the mandate of the people. Education will make humans more developed in developing and advancing the region. Because with education there will be more references and more strategies in developing regions.

The negative campaign is a strategy that is often used by political opponents. Therefore, $17 \%$ of respondents stated that they were not interested in negative campaigns. So on this occasion, the highest answer is a negative campaign. 
Respondents stated that negative campaigns tended to bring down political opponents who were not better off. Respondents considered that dropping an opponent was not commendable so that the respondent lacked sympathy with the candidate and also the successful team who threw accusations of negligence against their opponent.

Respondents who answered variously or as many as $6 \%$ of them had different answers because they came from different and diverse backgrounds so that they had opinions following culture, ethnicity, work education, and rules. For respondents, whoever leads is considered the same, so they answered in various ways. Of the 6 respondents, each of them had more than one answer which varied. This is because according to them the candidates have many shortcomings.

\section{CONCLUSION}

There was an answer from the respondent that the obstacle for a candidate to reach the top point of becoming a leader and being able to be elected by the people is on the negative side as the biggest obstacle followed by the second biggest obstacle is many promises. According to respondents, negative campaigns are things that are not responded to by respondents. Because according to them, those who raise about the opponent's shortcomings do not necessarily mean that they can cover up and not necessarily be able to do it better. Sometimes negative campaigns tend to lead to slander so that respondents are not interested in the negative campaign model, let alone the black campaign.

The second most common option is that there are many promises that every time there is competition on the political path, there will be promises which according to the respondents they are not kept. This means that respondents are increasingly not interested in candidates who often make promises. Moreover, according to respondents, they sometimes seem excessive. Respondents thought that promises that should be realized are often forgotten, especially if promises that are too high and too grandiose must only give false hopes, they think. The third barrier to becoming a winner is when the candidate is not smart in choosing a successful team so that the successful team is not solitary. When they are not solitary, the respondents 'aspirations will stop at the success team and not reach the candidates so that the respondents' aspirations have never been realized.

\section{REFERENCES}

Baharudin \& Umiarso. (2012). Kepemimpinan Pendidikan Islam Antara Teori dan Praktik, Jogjakarta: AR-RUZZ MEDIA.

Muhani., Imron, Ali., Kusmintardjo. (2016). Teori, Penelitian, dan Pengembangan. Jurnal Pendidikan, 8

Paksmp16kupangblog. (2016). Keterbatasan Manusia. Website: https://paksmp16kupangblog.wordpress.com/keterbatasan-manusia/

Usman, Husaini. (2013). Manajemen (Teori, Praktik, dan Riset Pendidikan) (Edisi ke Empat). Jakarta: Bumi Aksara.

Wahyudi. (2017). Manajemen Konflik dan Stres dalam Organisasi Pedoman Praktis bagi Pemimpin Visioner (H. Akdon Ed.). Bandung: Alfabeta.

Yamin, Martinis \& Maisah. (2010). Kepemimpinan dan Manajemen. Bogor: IPB Prees. 